\title{
Corruption and Economic Crimes in the Public Sector: A Case Study of Rwanda, Kigali.
}

\author{
Amara B. Kanneh \\ School of Post Graduate Studies, Kigali Independent University, Rwanda
}

\begin{abstract}
Corruption and Economic Crimes in the Public Sector is the topic of this research. Rwanda as a Case Study, this research used a descriptive survey with a quantitative approach. The study's target demographic was 400 respondents, many of whom were Rwandan private individuals and economists, and the sample size was 200. The study used a purposive sample approach and included closed-ended surveys of the population.
\end{abstract}

This study focuses on corruption and economic crimes in the public sector, with a specific focus on (NPPA), Rwanda, and Kigali. The study revealed several primary causes of corruption and economic crimes, ranging from poor administration to public society norms. Following the study, suggestions are made regarding the steps that the government, law enforcement agencies, ministries, and the general public will take to combat the threat (Okorie 2006)..

Keywords: Crimes, Corruption, Public Sector, Fraud, Financial, Accountability, Treasury

\section{Introduction:}

Economic crimes have been defined as the manifestation of a criminal act committed solely or in an organized manner, with or without associates or groups, with the intent to earn wealth through illegal means, carrying out illicit activities that violate the laws of the land and other regulating statutory provisions governing the government's and its administration's economic activities. It can destroy a country's trust in its system; endanger the integrity of government, its programs, and institutions, compromising national security, law and order. Overall, the prevalence of economic crime might make a country unappealing to investors (Okolie 2000). Regardless of the sophistication of the tactics used by thieves, the common traits of crime include cheating, lying, and stealing. Corruption is a threat in the public sector, and while it is a global problem, the breadth of its reach in the public sector was tragically vast. All signs indicated that the spread of this disease had reached alarming proportions. Corruption causes sluggish file movement in offices, police extortion at tollgates and slow traffic on roads, port congestion, lines at passport offices and petrol stations, phantom workers syndrome, and election irregularities, among other things. Even the insane on the street understand the devastation created by corruption - money designated for their wellbeing vanish into thin air.

Corruption is pervasive in all countries, and it is not limited to any continent, area, or ethnic group. Corruption exists under democratic and authoritarian governments, as well as feudal, capitalist, and communist economies. Corruption is not a new phenomenon; it has been for as long as the earth has existed. There is evidence of widespread criminality and corruption in ancient civilizations (Lipset and Lenz 2000). This commitment to combat corruption has resulted in financial prosperity. This East African country has served as a model for the continent. The country has reduced its reliance on contributions and now funds around 84 percent of the budget domestically, up from approximately 36 percent two decades ago. (World Bank Economic Report 2012) The National Public Prosecution Authority (NPPA) is a government organization tasked by the constitution with investigating and prosecuting all crimes committed within the country. Its purpose is to contribute to the security of people and their property by pursuing the perpetrators of violations and criminals and bringing them to justice in accordance with Rwanda's Constitution and International Law. (NPPA).

\section{Problem Statement}

Because of the administration's seriousness in combating corruption and economic crimes in the public sector, public employees in government ministries and agencies have summoned the bravery and discipline to safeguard the state treasury, but this is insufficient. Some civil workers commit these crimes because they have a connection to a high government official, and as a result, they are not penalized. Corruption affects every country. Abuse of public position for private 
benefit undermines people's faith in government and institutions, reduces the effectiveness and fairness of public programs, and diverts taxpayer funds away from schools, roads, and hospitals. Interference with the anti-graft authorities' functions, such as the Independent and Corrupt Practices Commission and the Economic and Financial Crimes Commission, in combatting the epidemic. The anti-graft agencies have been utilized to witch hunt any governmental workers who do not dance to the tune of the ruling party. The independence of anti-corruption authorities in punishing corrupt government officials in the ministry has been eroded. Corruption and economic crimes cause inefficiency and underutilization of public expenditures. Because of corruption and economic crimes in the public sector, the ministry has been unable to work efficiently and effectively with the resources that have been given to them. Officials in the public sector colluded with foreigners to commit corruption and found safe haven and acceptability overseas. Officials in the public sector are now involved in this behavior. For the past many years, this has resulted in misallocation and misallocation of resources allocated to the public sector in Rwanda. From the late 2000 s to the present, Rwanda has made significant progress in combating corruption and bringing public employees to public disgrace for unethical actions.

\section{Objectives of the Study}

Corruption and economic crimes have hampered the public sector's efficiency and development in providing services. In this regard, the research aims to: - Evaluate government initiatives targeted at reducing corruption and economic crime in the public sector.

- To ascertain the involvement of anti-corruption agencies.

- To assess the efficacy and usage of public expenditures by prosecuting arms of the Rwandan government.

- To assess the checks and balances in all areas of Rwanda's government involving public monies.

\section{Review of Literature}

Rwanda has evolved from a high degree of corruption to a level comparable to middle-income nations in 20 years. Its success in reducing administrative corruption - the type of corruption captured in international corruption assessments-is unprecedented for a country at Rwanda's level of economic development, and it stands in stark contrast to the bleak experiences of other countries emerging from conflict and violence in combating corruption. While administrative corruption has not gone, it has significantly diminished and developed from an acceptable practice to one that is recognized as illegal and, once detected, punishable. Rwanda's establishment of a rule-based, law-abiding public sector is a remarkable development achievement that

\section{ISSN 2455-6378}

deserves to be recognized both for its own sake and for the lessons it can offer other countries struggling to combat corruption from a position of limited public sector authority and competency, shallow private sector markets, and fractured and fragmented civil society.

Corruption is regarded as a significant impediment to progress and development. The scholarly research, on the other hand, shows varying consequences of corruption on economic performance. Since the late 1990s, prominent government officials have viewed the battle against corruption as critical to breaking the cycle of violence that had previously resulted in genocide. The government's zero tolerance for corruption policy was based on the notion of corruption as a threat to society. This image is also reflected in the relationship between corruption and injustice, which influenced the establishment of the Office of the Ombudsman to lead the anti-corruption campaign. While altering norms and standards served as the societal basis for anti-corruption efforts, preventing corruption and penalizing wrongdoing have been the fight's twin pillars. The initial set of market reforms implemented in the early 2000s significantly limited possibilities for corruption. Trade and foreign exchange regime liberalization decreased pricing distortions and eliminated chances for arbitrage and rent seeking. Opportunities for corruption have been reduced further by enhancing the application of corporate regulations and removing superfluous rules and processes. At the same time, Rwanda's public procurement regulations were revised, and the National Tender Board (now Rwanda's Public Procurement Authority) was established, allowing Rwanda to achieve more openness and consistency in the state's contracting with the private sector. Rwanda's consistent and remarkable growth in the Doing Business rankings attests to these achievements, even while the state continues to dominate the economy. The government has worked tirelessly to combat corruption by recognizing and decreasing corruption's susceptibility. Working across institutional boundaries, the Ombudsman, Auditor General, and Parliamentary Accounts Committee have developed an iterative process for determining where the risks of administrative corruption are greatest, providing clear instructions on corrective actions for ministries, agencies, and other administrative units, and following up to ensure action is taken. Administrative and individual sanctions have been imposed on authorities and institutions considered to be unresponsive. Individual institutional mandates have been changed to improve the overall efficacy of anti-corruption efforts, expanding organizational skills. The use of contemporary information technology in validating asset declarations, integrating financial management 
information systems, and controlling the procurement process has significantly aided anticorruption operations. Individuals and communities have banded together to combat corruption. Several public awareness initiatives have emphasized the necessity of reporting suspected corruption. Across the country, annual village-level activities urge communities to be vigilant - and explicitly communicate that the government expects residents to be the first line of defense against corrupt individuals (2020 World Bank Anti-Corruption Index-Rwanda).

Although this trend is remarkable, it does not conceal the reality that corruption remains a problem in Rwanda. Interviews with police officers, public employees, company owners, and ordinary individuals continue to produce examples of recent contacts with corruption. Ethnographic research, such as Rollason's (2019) investigation of the moto-taxi business in Kigali, indicate that corruption is still a part of daily life, particularly for those who deal with corrupt sectors, such as the traffic police. Some 18.5 percent of those polled for Transparency International Rwanda's (2019a) Rwanda Bribery Index had faced corruption in the previous year, a high figure in Rwanda. Thus, the purpose of this study is not to argue that corruption has vanished in Rwanda. Its purpose is to investigate the factors that have contributed to its considerable decline and its change from an acceptable activity to one that is considered as illegitimate and, once detected, punishable.

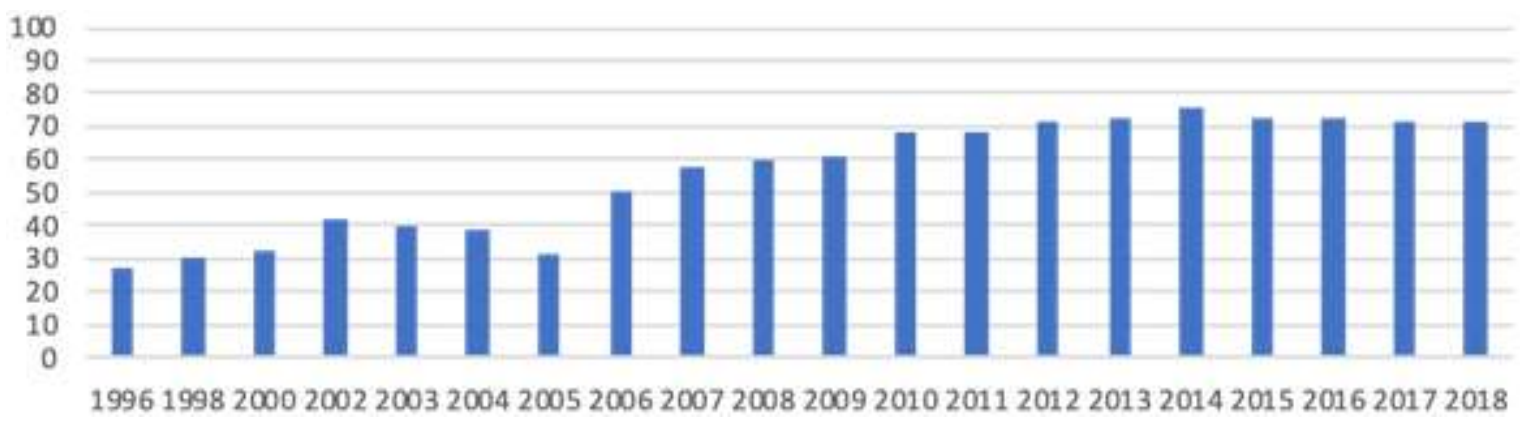

Figure 1: Rwanda's performance on the control of corruption index, 1996-2018

Source: Control of corruption, World Bank's World Governance Indicators - Percentile rank among all countries, World Bank (2019c)

Source: Controlof corruption,World Bank's WorldGovernance Indicators - Percentile rank among all countries, WorldBank(2019c)

Rwanda's strategy emphasizes centralized resource allocation to generate results that are compatible with government goals for sector and regional development. For example, "signature" policies may be observed in how the government promotes agricultural and business sectors through aggressive and interventionist policies that usually incorporate state-owned enterprises. They are also seen in Rwanda's distinctive characteristics of urbanization and public infrastructure investments, which are aimed toward fulfilling the government's long-term goal rather than being driven only by market signals and existing endowments and scarcities (World Bank 2019b). This public-sector involvement distinguishes Rwanda from other nations with a successful anti-corruption track record. What action was taken? Rwanda's anticorruption initiatives Rwanda's anti-corruption efforts were successful because they addressed three dimensions at the same time: changing social norms about corruption and expectations about acceptable official behavior (the foundation), preventing corruption from occurring, and sanctioning individuals and institutions for corrupt practices. This strategy prioritized honesty while building a strong institutional and legal structure that was fit for purpose.

To combat graft, Rwanda established an Ombudsman agency. The office has the authority to investigate and prosecute. At the Intermediate Court, it also has specialized chambers dealing with corruption. A national-level advisory council against corruption and injustice was established to direct tactics and increase information exchange on corrupt behavior.

Rwanda is also a member of the East African Association of Anti-Corruption Authorities and its asset recovery subgroup, as well as the Commonwealth Africa Anti-Corruption Centre, the African Union Advisory Board on Corruption, the United Nations Office on Drugs and Crime, and others. 
According to World Bank rankings, Rwanda has achieved significant improvement, going from a score of $26 \%$ in 1996 to $71 \%$ in 2017 . Rwanda was placed 48 on Transparency International's 2018 Corruption Perceptions Index, up from 83 in 2005 and 121 in 2006. This is a significant step forward.

In September 2018, Rwanda enacted a new law to combat corruption, broadening the definition of corruption to include bribery, sexual corruption, embezzlement, making decisions based on favoritism, friendship, or hatred, influence peddling, illicit enrichment, use of public property for unintended purposes, abuse of power, and demanding or receiving undue or excessive money.

\section{Methodology}

Research design, data collection, data analysis

This chapter emphasized the research design, target population, research instrument, data analysis, validity, and reliability of the study, removal of bias, and ethical issues for this study. Secondary data was also gathered from other sources, such as information gathered and used by others in the past. The study's target demographic was 400 respondents, many of whom were Rwandan private individuals and economists, and the sample size was 200. The study used a purposive sample approach and included closed-ended surveys of the population. Nonprobability and probability techniques were utilized in the investigation.

The study design process is systematic in the sense that establishing the aim, handling the data, and conveying the findings all take place within defined frameworks and rules. As a result, this study used a descriptive survey with quantitative data methods. In this study, the researcher collected data from respondents using a standardized questionnaire and interview guide. The primary and secondary data sources used in the study were both primary and secondary. In terms of field data collection, the study included a questionnaire and an interview guide.

Table 1: Respondents Types

\begin{tabular}{|l|c|c|c|}
\hline $\begin{array}{l}\text { TARGET } \\
\text { INSTITUTIONS/RESPONDENTS }\end{array}$ & TARGET POPU. & PROPORTIONS & SAMPLE SIZE \\
\hline Transparency International & & & \\
\hline Ministry of Finance/Rwanda & 60 & $40 \%$ & 25 \\
\hline National Public Prosecution Authority & 30 & $1 \%$ & 10 \\
\hline Economists & 22 & $2.20 \%$ & 10 \\
\hline Rwanda Public Procurement Authority & 36 & $1.50 \%$ & 15 \\
\hline Office of the Ombudsman & 40 & $2 \%$ & 20 \\
\hline Total & $\mathbf{2 0 8}$ & $\mathbf{4 8 \%}$ & $\mathbf{1 0 0 \%}$ \\
\hline
\end{tabular}

Source: Researcher own design, 2021

The study's target demographic was 400 respondents, many of whom were Rwandan private individuals and economists, and the sample size was 200. According to the study's methodology, the Morgan simple table and pie and bar conversations were utilized to gain understanding:

\section{Results and Discussion}

Respondents' Demographic Characteristics The respondents were mostly between the ages of 18 and 55 , accounting for 37.3 percent of the total. The majority of personnel particularly work in Rwanda Public Procurement Authority, Ministry of FinanceRwanda, Economists, National Public Prosecution Authority/ and private people with great knowledge of the topic. 
Figure 2: Rwanda's holistic approach to addressing corruption

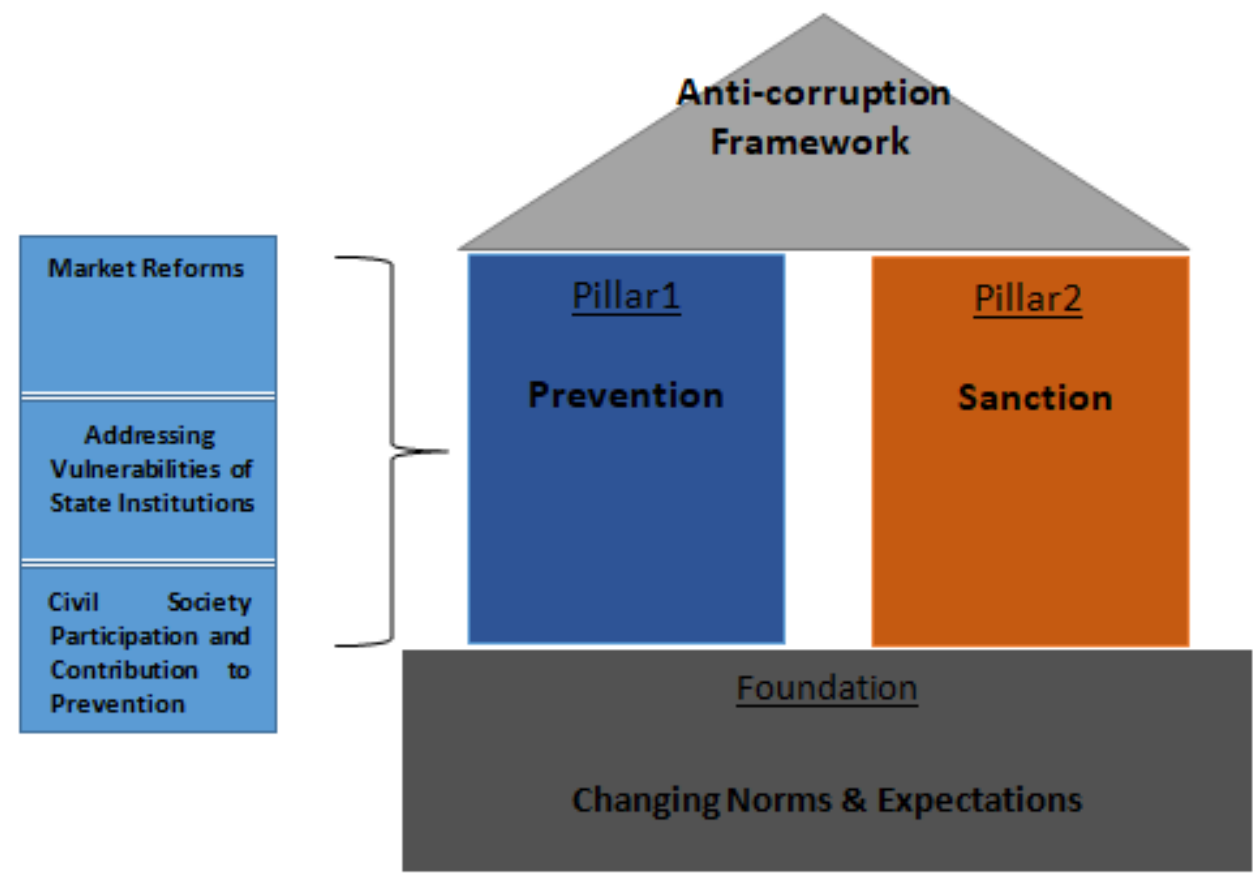

Source: World Bank (2019)

Corruption is dangerous to the public sector of Rwanda.

\begin{tabular}{|l|l|l|}
\hline $\begin{array}{l}\text { Respondents' } \\
\text { responses }\end{array}$ & Frequency & Percentage \\
\hline Strongly Agree & 47 & 58.75 \\
\hline Agree & 18 & 22.5 \\
\hline Strongly Disagree & 5 & 6.25 \\
\hline Disagree & 20 & 12.5 \\
\hline TOTAL & $\mathbf{1 0 0}$ & $\mathbf{1 0 0}$ \\
\hline
\end{tabular}

Source: Research Questionnaire
Corruption hinders economic growth of a nation.

\begin{tabular}{|l|l|l|}
\hline Respondents' Responses & Frequency & Percentage \\
\hline Yes & 60 & 76.25 \\
\hline No & 40 & 23.75 \\
\hline TOTAL & $\mathbf{1 0 0}$ & $\mathbf{1 0 0}$ \\
\hline
\end{tabular}

Source: Research Questionnaire

The Rwandan government is strongly against corruption in the public sector.

\begin{tabular}{|l|l|l|}
\hline Respondents' Responses & Frequency & Percentage \\
\hline Yes & 72 & 52.5 \\
\hline No & 28 & 47.5 \\
\hline TOTAL & $\mathbf{1 0 0}$ & $\mathbf{1 0 0}$ \\
\hline
\end{tabular}

Source: Research Questionnaire 
Figure 3: Cases of corruption processed by the Office of the Ombudsman, 2006-07 to 2018-19

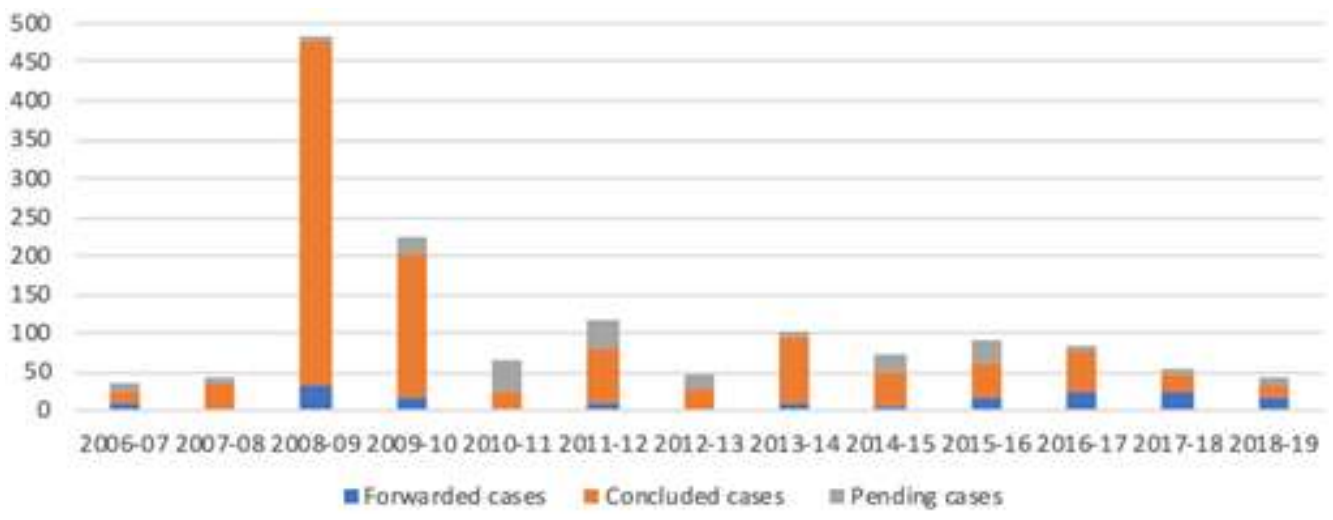

Source: Ombudsman annual reports.

\section{Secondary Data:}

In Rwanda, zero tolerance is not just, or even largely, signaled through anti-corruption initiatives. It has mostly been accomplished by the President's recurrent participation on the subject in national forums such as the annual National Dialogue (Umushyikirano) and continual disclosure to the public about arrests-for example, through the publishing of a convict database (see below). Making high-profile corruption cases public is also an important part of the signaling strategy. According to a top official in the justice sector, anti-corruption efforts in Rwanda focus on those in positions of authority and responsibility in order to send a strong message to the entire community. The Inspectorate of Police Services and Ethics, formed by the Rwanda
National Police in 2013, comprises an AntiCorruption Directorate and an Ethics Center. It also offers a toll-free hotline where anyone may report incidents of corruption (Lamarque 2017). Many anecdotes about how the police detect corrupt personnel circulate in Rwanda. Several responders (not from the police or the Investigation Bureau, for example) claimed that the police deploy plainclothes officers to solicit bribes and capture corrupt officials red-handed. Other responses said that traffic police are instructed to put any personal cash in their locker before to their duty and that they can be inspected after their shift for any cash on their person, which would result in their immediate dismissal.

Table 2: A non-exhaustive list of police officer firings because of professional malpractice or gross misconduct (including corruption), 2006-18

\begin{tabular}{|c|c|}
\hline Year & Action \\
\hline 2006 & 120 police officers fired for corruptiona \\
\hline 2007 & 314 police officers fired for corruption ${ }^{\mathrm{a}}$ \\
\hline 2008 & 141 police officers fired for corruption ${ }^{a}$ \\
\hline 2009 & 73 police officers fired for corruption ${ }^{a}$ \\
\hline 2011 & Police officers fired for corruption and other unethical conduct by Cabinet decision ${ }^{\text {b }}$ \\
\hline 2012 & 48 police officers fired for corruption, 77 charged with corruption ${ }^{c}$ \\
\hline 2013 & 49 police officers charged with corruption ${ }^{c}$ \\
\hline 2014 & $\begin{array}{l}74 \text { senior police officers, including the two directors of intelligence in the } \\
\text { Criminal } \\
\text { Investigations Department, fired by presidential order }{ }^{\mathrm{d}}\end{array}$ \\
\hline 2017 & 198 police officers fired ${ }^{\mathrm{e}}$ \\
\hline 2018 & 189 police officers fired $^{\mathrm{d}}$ \\
\hline
\end{tabular}

Source: https://www.newtimes.co.rw/section/read/12831 
Figure4:Citizens perception level of $\operatorname{corruption}(n=2,287)$

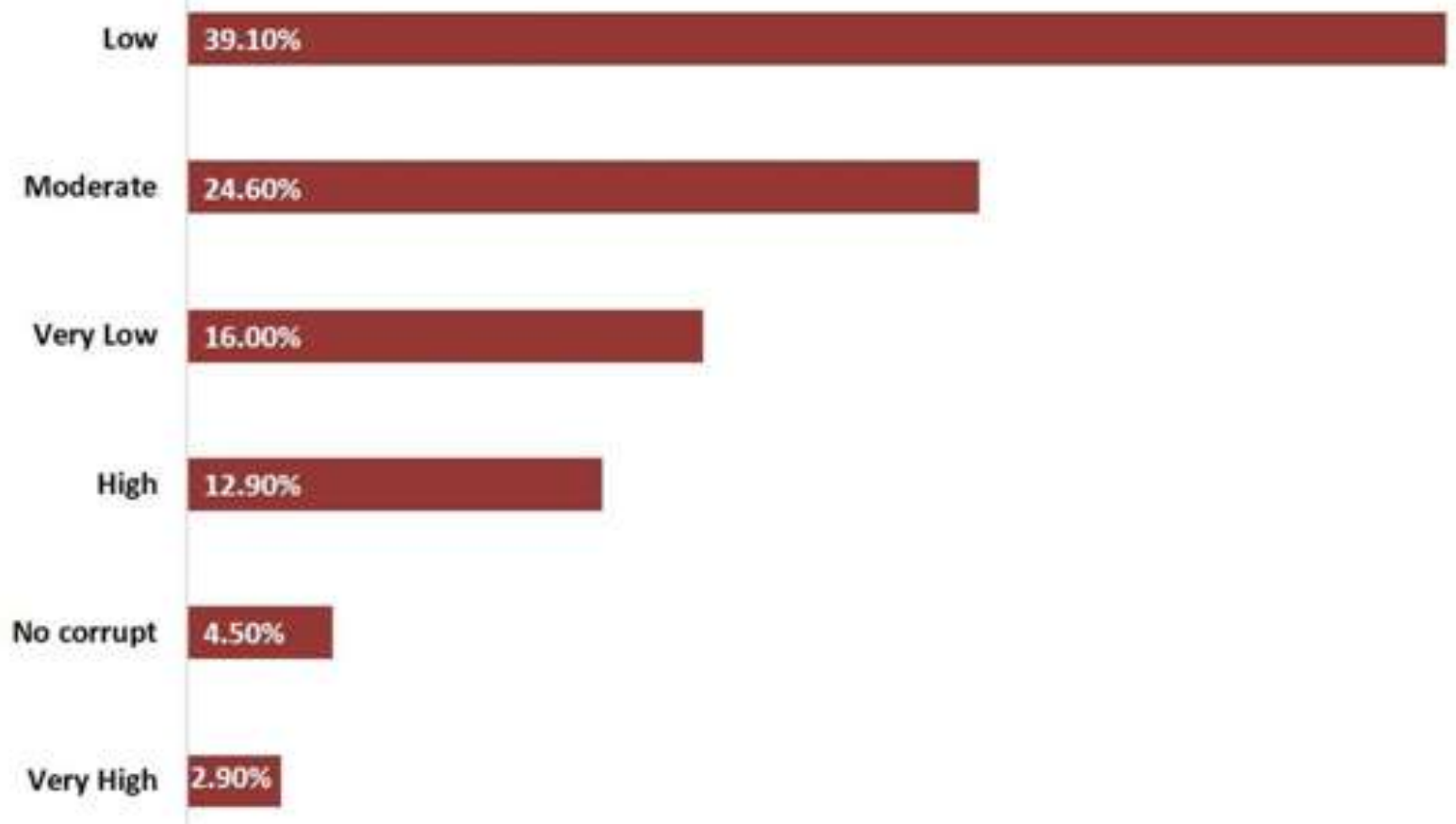

\section{Source:TI-RwandaRBI2017}

\section{Secondary Data:}

The government has also altered individuals' expectations of the state by increasing citizens' understanding of their rights and how the government should function in relation to citizens. The first Ombudsman, Tito Rutaremara, argues that this was one of the primary motivators behind the establishment of the Office of the Ombudsman: "The objective was to punish, but more importantly, to educate people about their rights." The objective of the 2012 ruling that every government entity should adopt a service charter was to educate individuals about their rights. Charters specify what sorts of services residents may anticipate and when they will receive them. Charters, however, were not conceived merely as a customer service measure; they are also tools for increasing openness and accountability in interactions between residents and the state. According to Anastase Murekezi, the Public Service Minister at the time, service charters "would help prevent many situations that have been persistent in the service sector, such as corruption, because a person will now know when a service is delivered." Many municipal authorities have a habit of extending some services in order to obtain bribes." 16 Service charters are posted in administrative buildings and on the websites of public entities.

\section{Pillar 1: Prevention}

While changing norms and standards formed the foundation for Rwanda's anti-corruption effort, the fight against corruption has been pursued primarily through a balanced two-pillar strategy to prevent corruption from taking place and to sanction public officials who engage in corrupt practices. Prevention has been a three-pronged effort in Rwanda. It consists of pursuing market reforms, reducing the vulnerability of state institutions, and sensitizing the community to corruption issues.

\section{Pursuing market reforms}

As Rwanda regained peace and stability in the late 1990 s and early 2000s, the government started on socalled first-generation reforms to reinforce the market economy's basis and enhance the business climate. The liberalization of trade and exchange systems, which removed massive pricing distortions and the accompanying incentives and possibilities for corruption, was one of the most important changes. In 1996, interest rate controls were abolished; a flexible exchange rate system was subsequently implemented, and most restrictions on foreign exchange, including import and export activities, were repealed.

The Rwanda Utilities Regulatory Authority was established in 2001 as a major step toward improving service delivery and strengthening utilities' financial performance by introducing transparent tariff-setting mechanisms and prioritizing cost-recovery by reducing losses caused by mismanagement and corruption. The significant privatization of state businesses in the banking and non-banking sectors in 
the early 2000s further indicated the government's aim to limit the state's involvement in the economy and allow the private sector to drive investment and growth.

- It also introduced strict time limits for some procedures, including issuing tax clearance certificates, the lengthiest part of the process. As a result, the number of days needed for property registration has dropped from 371 to 7 , and the cost has dropped from around 10 percent of income per capita to 0.1 percent. Since 2005 the government has greatly strengthened contract enforcement by establishing more commercial courts and creating the Business Law Reform Cell, whose review of 14 commercial laws proved crucial in the approval of important legal reforms. The government further enhanced the court system in 2008 by creating lower commercial courts. Consistent with its emphasis on bringing in the skills and expertise needed to ensure the success of the reform process, the government also hired non-Rwandan expatriate judges to help local judges run the new commercial courts during the first three years of operation. Moreover, the Capacity Strengthening Program and the Institute for Legal Practice are training judges, legal officers, and lawyers to work in a mixed legal system, where the civil law tradition dominates but common law and customary law tendencies are also evident.

\section{Source: Traore et al. 2013.}

Figure 5: Rwanda's ranking among 190 countries in doing Business dimensions, 2020

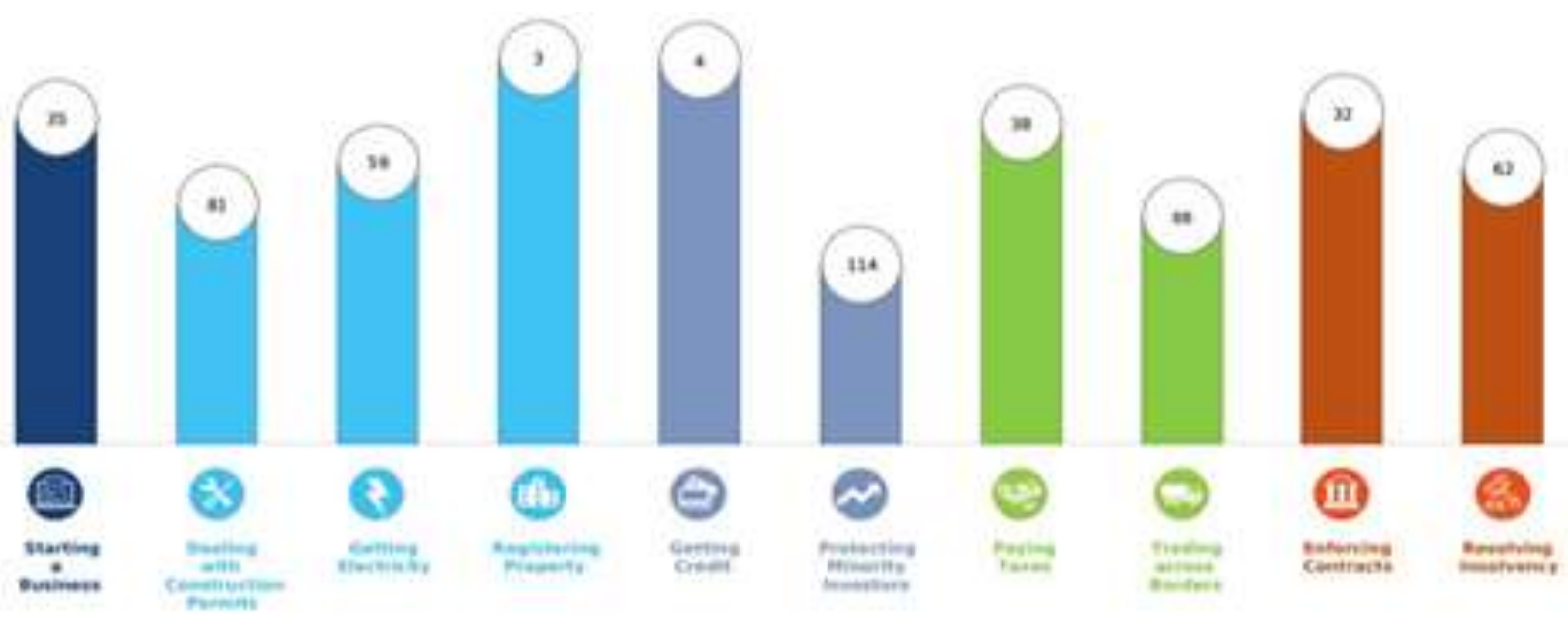

Source: World Bank Doing Business ranking (World Bank, 2020).

Market reforms have been accompanied by prudent macroeconomic management. Inflation has been kept under control, and the exchange rate has been stable, thanks to careful management of foreign exchange reserves and to sheltering of public expenditure from the impact of electoral cycles (figure 6); Chemouni 2019).

The Office of the Ombudsman's risk analysis is guided by a broad range of public information sources. The Preventing Corruption and Related Offenses Unit uses Office of the Auditor General annual reports, citizen complaints, media reports, and tips from informants to target specific sectors (such as sport as in 2013 or education as in 2019) or geographic areas (such as a given province) deemed particularly vulnerable to corruption. The Office of the Auditor General is also involved in preventing corruption by auditing governmental fiduciary systems and issuing recommendations in its annual report. The recommendations are also closely monitored by Parliament's Public Accounts Committee, which reviews their implementation status and can conduct fieldwork to verify the status and summon. The government began utilizing the Doing Corporate report in 2007 to discover and learn from best practices in business regulation, as well as to evaluate progress (Traore et al. 2013).

Rwanda has also made property transfers easier. Rwanda abolished mortgage registration costs in 2008 and switched from a $6 \%$ transfer tax to a flat rate. The government decentralized the Office of the Registrar of Land Titles in 2010 and established five branches around the nation, clearing the backlog of cases in Kigal. Officials will provide explanations in public sessions (see below). Failure to implement may result in administrative consequences against the officials involved. 
Figure 6: Implementation status of Office of the Ombudsman recommendations, 2010-11 to 2018-19

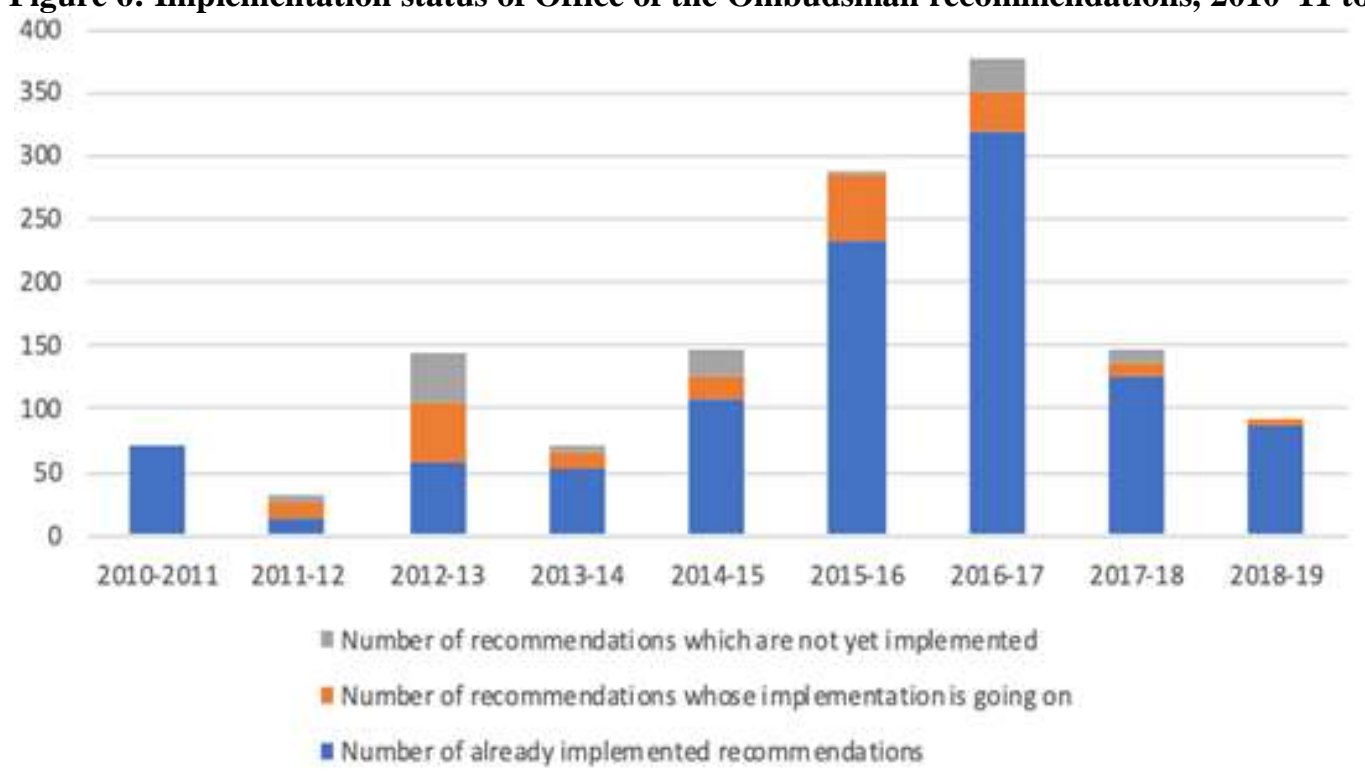

Educating the community

The Rwanda National Police, the Rwanda Bureau of Investigation, Transparency International Rwanda, African Parliamentarians Network Against Corruption (APNAC), and the Office of the Ombudsman are all participating in anti-corruption efforts. These institutions have utilized a variety of avenues to create a more aware population. It is difficult for Rwandans to ignore the anti-corruption message. It is disseminated through the national anticorruption campaign, which is held every year around International Anticorruption Day, December 9, and African Anticorruption Day, July 11, and typically includes village-to-national outreach, focus groups with young people, a conference with the Private Sector Federation, Women's Anticorruption Day, and the Rwanda Investigation Bureau's Anticorruption Unit. Furthermore, institutions send out targeted messages throughout the year via youth groups, the private sector federation, procurement trainings provided by the Rwanda Public Procurement Authority, and other ad hoc activities. The Ombudsman's Office also conducts anticorruption groups in schools and works with churches to raise awareness about religious events. During the annual anti-corruption week in 2015, 17 commercial radio stations broadcast anti-corruption discussion shows:

\section{Pillar 2: Sanctions}

Individuals who participate in corrupt activities are sanctioned as the second pillar of Rwanda's anticorruption measures. Rwanda has committed significant resources in developing fundamental capabilities across the whole sanctioning process, from identifying corrupt activities to investigating and punishing misconduct and recovering criminal proceeds.

\section{Detecting bribery}

Rwanda has robust institutional systems in place to identify corruption. This is not the work of a single organization. The Office of the Ombudsman and the Rwandan Investigation Bureau are the key players in the investigation. Around $80 \%$ of corruption cases identified by the Office of the Ombudsman are the result of citizen complaints sent by phone, internet, or in person, while $15 \%$ of cases are the result of asset declarations submitted to the office.

The detection is aided by the disclosure of officials' assets, which has been a constitutional requirement since 2003 for politicians, top public workers, and any authorities who manage money. The number of officials required by law to register their assets has grown over time to over 12,000 . This has coincided with an increase in compliance (figure 6). The declaration procedure has been substantially enhanced by computerization since 2003. Individuals who have failed to disclose their assets are tracked down in a methodical manner to guarantee compliance. Individuals who failed to disclose assets had their identities routinely exposed in the news between 2005 and 2010. Failure to report assets may also result in a warning letter, an official reprimand, a three-month suspension, or a pay decrease. In 2016-17, for example, the 53 people who did not make their declaration on time had $25 \%$ of their monthly pay withheld and were forced to account for their assets. 
To preserve its independence, the Office of the Ombudsman in Rwanda is exclusively responsible for selecting which complaints to pursue. When each institution has launched its own investigation, investigations can be undertaken together with the Rwanda Investigation Bureau. 28 If the Office of the Ombudsman is unable to handle a matter, it may send it to the Rwanda Investigation Bureau. The legislation permits these organizations to use a variety of investigative tools, including as eavesdropping, paying informants, and removing professional confidentiality if it is an impediment to the inquiry. The Rwanda Investigation Bureau can also send in undercover agents to catch corrupt citizens red-handed.

Prosecution and punishment have likewise evolved to meet the demands of the anti-corruption campaign. Since 2018, the Rwandan National Public Prosecution Authority and the Office of the Ombudsman have shared prosecutorial authority in corruption cases. This power was not granted to the latter until 2013. The mechanisms driving this evolution and the 2009 change providing investigative powers to Office of the Ombudsman agents are substantially identical (Chemouni 2017): a reaction to bottlenecks in anti-corruption operations. While the investigation had improved, the prosecution had become a weak link. Prosecutors did not always have the necessary knowledge to grasp corruption charges, which sometimes need excellent accounting abilities. More importantly, it was alleged that certain magistrates were readily paid by suspects, jeopardizing prosecution on a frequent basis. To resolve the issue, the Ombudsman recommended for internalizing prosecution in order to speed its work, maintain the process's independence, and prevent influence. Despite opposition from a judiciary sector unwilling to accept division of prosecutorial authority, the change was easily enacted in 2013 owing to the backing of the President's Office and Members of Parliament who had previously decried the backlog.

Sentencing in corruption cases has become much better over the years. First, the integration of prosecution in the Ombudsman's Office appears to have increased the conviction rate to more than $80 \%$, which is equivalent to the National Public Prosecution Agency's conviction rate for all offenses. Furthermore, the introduction of a separate chamber of judges for economic crime in 2018 enhanced sentence. Finally, a legislative structure that matches the country's zero-tolerance stance has made punishment easier. The new anti-corruption legislation mandates a minimum penalty for all corruption offenses. For example, soliciting or offering a bribe carries a minimum punishment of 5 years in prison (article 4). The minimum penalties are tougher for members of the judiciary ( 7 years) and judges (10 years) (article 5). Finally, the 2018 law broadened the concept of corruption to include embezzlement and function abuse. These activities have always been prohibited, but they are now subject to a tougher punishment structure for corruption offenses.

\section{Conclusion}

Corruption is pervasive in all countries, and it is not limited to any continent, area, or ethnic group. Corruption exists under democratic and authoritarian governments, as well as feudal, capitalist, and communist economies. Corruption is not a new phenomenon; it has been for as long as the earth has existed. There is evidence of widespread criminality and corruption in ancient civilizations. Economic crimes have been defined as the manifestation of a criminal act committed solely or in an organized manner, with or without associates or groups, with the intent to earn wealth through illegal means, carrying out illicit activities that violate the laws of the land and other regulating statutory provisions governing the government's and its administration's economic activities. Rwanda has made significant success among African countries in combating corruption in the public sector.

\section{Acknowledgement}

I am grateful to God for the good health and wellbeing that were necessary to complete this project. I take this opportunity to express gratitude to all of my respondents for their help and support. I wish to express my sincere thanks to my colleagues from the Masters of Development Studies Department, ULK, for providing me with all the necessary guidance as well. I place on record, my sincere thanks to my professional colleague in Cyprus, Europe, Mr. Kaiballah Conteh for being one of my staunch peers' reviewers. I am also grateful to the International Journal of Advanced Scientific Research and Management editorial team for their unwavering support towards the promotion of generational leaders through extensive and independent research.

\section{References}

[1] Andrews, M. 2013. The Limits of Institutional Reform in Development: Changing Rules for Realistic Solutions. Cambridge, UK: Cambridge University Press. Baez-Camargo, C., T. Gatwa, A. Dufitumukiza, C. Stahl, and S. Kassa. 2017.

[2] Behavioural Influences on Attitudes towards Petty Corruption: A Study of Social Norms, Automatic Thinking and Mental Models in Rwanda.

[3] Basel, Switzerland: Basel Institute on Governance. Baez-Camargo, C. and G. Tharcisse. 
2018. Informal Governance and Corruption Transcending the Principal Agent and Collective Action Paradigms.

[4] Rwanda Country Report. Basel, Switzerland: Basel Institute on Governance. Behuria, P. 2012. "Centralising Rents and Dispersing Power While Pursuing Development? Exploring the Strategic Uses of Military Firms in Rwanda." Review of African Political Economy 43 (150): 63047.

[5] Behuria, P., and T. Goodfellow. 2019 "Leapfrogging Manufacturing? Rwanda's Attempt to Build a Services-Led

[6] 'Developmental State." European Journal of Development Research 31 (3): 581- 603.

[7] Beschel, R., B. Cameron, J. Kunicova, and B. Myers. 2018. Improving Public Sector Performance through Innovation and Inter-Agency Coordination: Global Report Public Sector Performance.

[8] Washington, DC: World Bank. Booth, D. and F. Golooba-Mutebi. 2012. "Developmental Patrimonialism: The Case of Rwanda." African Affairs 111 (444): 379-403. Bozzini, A. 2014. "Background Paper on Rwanda".

[9] Berlin: GIGA German Institute of Global and Area Studies. Chemouni, B. 2014. "Explaining the Design of the Rwandan Decentralization: Elite Vulnerability and the Territorial Repartition of Power." Journal of Eastern African Studies 8 (2): 246-62. Chemouni, B., 2016. "Taking stock of
ISSN 2455-6378

Rwanda's decentralisation: changing local governance in a post-conflict environment." Third World Thematics:

[10] A TWQ Journal, 1(6), pp.763-778. Chemouni, B. 2017. "The Politics of Core Public Sector Reform in Rwanda." ESID Working Paper 88/2017. University of Manchester, Effective States and Inclusive Development Research Centre, Manchester, UK. http://www.effectivestates.org/working-paper-88/.

[11] Olken, B.A., 2009. "Corruption perceptions vs. corruption reality." Journal of Public economics, 93(7- 8): 950-964.

[12] Office of the Ombudsman (different years). Annual Report. Kigali: Government of Rwanda Persson, A., Rothstein, B. and Teorell, J. (2013), "Why Anticorruption Reforms Fail-Systemic Corruption as a Collective Action Problem".

[13] Governance, 26: 449-471. Traore, M., A. F. Gonzalez, C. Chaparro Yedro, J.-M. Lobet, and J. Bailey. 2013. Doing Business 2013: Rwanda: Fostering Prosperity by Promoting Entrepreneurship. Washington, DC: World Bank.

[14] Transparency International. 2019. Corruption Perceptions Index, https://www.transparency.org/en/ cpi. Transparency International Rwanda. 2018. Rwanda Bribery Index 2018. Kigali. Transparency International Rwanda. 2019a. Infographics for the Rwanda Bribery Index 2019. Kigal 